\title{
HAMSUKKĀN IN ISAIAH 40:20: \\ SOME REFLECTIONS ${ }^{1}$
}

\author{
Simon Sherwin
}

\begin{abstract}
Summary
Hamsukkān in Isaiah 40:20 has been linked with Akkadian musukkannu, a type of wood. This article examines the geographical spread of the wood in antiquity in order to determine what implications the acceptance of this reading has for the dating of the text.
\end{abstract}

\section{Introduction}

The idol polemic of Isaiah 40:18-20 is notoriously difficult and has been discussed many times over the years. It is not the purpose of this brief article to reopen all the issues involved. Rather, the intention is to examine one particular proposal that has been made, that is, that

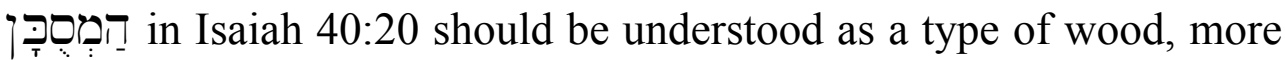
specifically, that it corresponds to Akkadian musukkannu, ${ }^{2}$ and the implications of this proposal for the dating of the idol polemic itself.

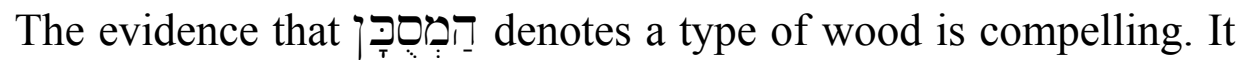
has been frequently observed that Jerome, the Targum and $\mathrm{Sa}^{\text {'adya }}$ understood it this way. Jerome, for example, wrote in his commentary on Isaiah, 'in Hebraeo dicitur amsuchan; quod genus ligni est imputribile, quo vel maxime idola fiunt'. ${ }^{3}$ However, there is no indication from this that he understood which species of tree was

1 I am grateful to the British Academy for a Postdoctoral Fellowship which enabled me to research this article.

2 musukkannu, gišMES.MÁ.GAN.NA has been fairly definitely identified as sissoo-wood (Dalbergia Sissoo Roxburgh), a black wood, similar in appearance to ebony, which grows in Iran, Oman and the Indus valley. See, in particular, I. Gershevitch, 'Sissoo at Susa', Bulletin of the School of Oriental and African Studies 19 (1957) 317-20; K.R. Maxwell-Hyslop, 'Dalbergia Sissoo Roxburgh', Anatolian Studies 33 (1983) 67-72.

3 See, conveniently, H.G.M. Williamson, 'Isaiah 40,20 - A Case of Not Seeing the Wood for the Trees', Biblica 67 (1986) 12. 
being referred to, since what he says about it is contained in the text itself. ${ }^{4}$ The Targum and Sa'adya translate it as 'pine' and 'oak'

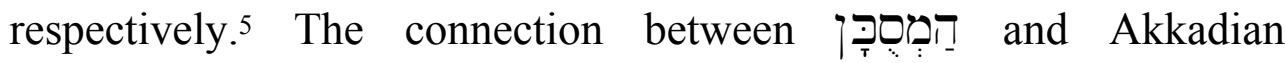
musukkannu was drawn as early as 1894 by $\mathrm{H}$. Zimmern, ${ }^{6}$ and has been followed sporadically since, but has by no means gained universal acceptance. In its favour is the Masoretic vocalisation, which corresponds exactly with the Akkadian variant spelling mesukkannu. This is incidentally an important witness to the antiquity and conservatism of the Masoretic vocalisation which was maintained despite the fact that (on the testimony of the ancient versions) the word itself was no longer understood. A third piece of evidence in its favour is the phrase found in our verse, עיץ ל'אייריקב, 'a tree that will not rot'. musukkannu-wood in Akkadian is on several occasions described as ișsu dārû, 'everlasting wood'.7 The evidence that we

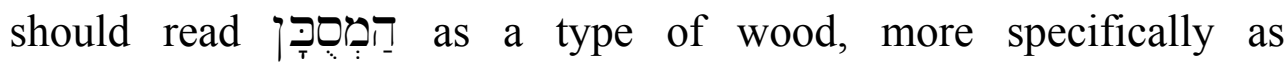
musukkannu, 'sissoo-wood', is therefore compelling.

\section{Implications}

If this is to be accepted, what implications does it have for the passage in which it is found? H.G.M. Williamson, for example, says in the concluding remarks of his article on this verse, 'the evidence used has come from the language and the period most closely associated with the setting which is generally, and in my view rightly, presupposed for this author'. ${ }^{8}$ Whilst in this case it may well be that a supposed Babylonian background and setting for Isaiah 40 has led to the correct interpretation of the word, can this be used as evidence to support the idea of a prophet who lived and worked in Babylonia in the sixth

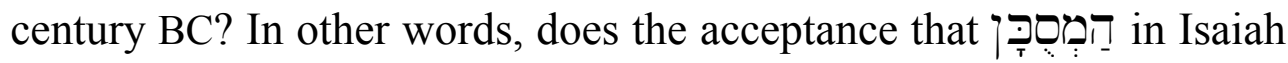

\footnotetext{
4 'quo vel maxime idola fiunt' could be taken as a logical extension of understanding v. 20 as the creation of a wooden image. Why should the author refer to a specific type of wood if it were not the case that images were frequently constructed from it?

5 Williamson, 'Isaiah', 12.

6 H. Zimmern, 'me̊sukkân Jes. 40,20=ass. musukkânu "Palme", ZA 9 (1894) 111-12. As the title suggests, he thought musukkannu meant 'palm'. However, the identification by Gershevitch is convincing.

7 CAD D dārû 2b, p. 118.

8 Williamson, 'Isaiah', 19.
} 
40:20 means 'musukkannu-wood' exclude either a Western or preexilic origin for the idol polemic in which it appears??

It must be acknowledged that a Babylonian setting would fit quite well. The wood was fairly widely used in the Neo-Babylonian period, particularly in monumental architecture. It was used alongside such other woods as cedar, pine and cypress for a variety of purposes within temples, including beams and doors. ${ }^{10}$ Not only so, but it was also used for making furniture. ${ }^{11}$ A rather elaborate example from the inscriptions of Nabonidus speaks of a table of musukkannu-wood, overlaid with pure silver and shining gold, made for the goddess Ištar and set before her. ${ }^{12}$ The wood was therefore available and known in Babylonia during the Neo-Babylonian period. Indeed although, as its

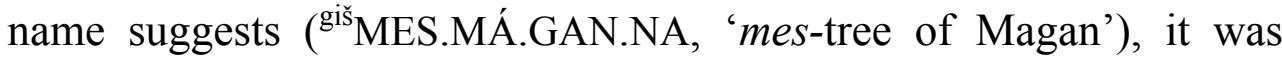
originally a foreign import, it is likely that it could be found growing in Babylonia itself at the time. In the reign of Tiglath-Pileser III of Assyria (744-727 BC) there was a plantation of musukkannu-trees growing in the south of Babylonia, in the territory of Bit-Amukkani, which he felled..$^{13}$ It is not unreasonable to suppose, therefore, that there were other plantations of the tree in Babylonia two hundred years later.

However, the use of musukkannu-wood in monumental architecture and for furniture was neither restricted to Babylonia, nor to the Neo-Babylonian period. The wood was used on a number of occasions by Assyrian kings, and was cultivated in Assyria itself by Assurnasirpal II (883-859) and Sennacherib (704-681). ${ }^{14}$ It is also found, albeit more rarely in extant records, in texts from the Old and Middle Babylonian periods. Its usage on these occasions seems to be more in items of furniture. In the Old Babylonian period the wood had

9 The reason why this question is at all pertinent is that the idol polemic in Is. 44:9-20 can be shown to have originated in the west either in the pre-exilic or early exilic period. If this is the case for the longest and most developed of the idol polemics, could it also be the case for others?

10 See, for example, Nabonidus' renovation of the Ebabbar temple of the god Šamaš in Sippar, now conveniently contained in H. Schaudig, Die Inschriften Nabonids von Babylon und Kyros' des Großen (AOAT 256; Münster: UgaritVerlag, 2001) p. 386, 2.91 II 3-5, with translation on p. 393.

11 See CAD M/ii musukkannu b 2', p. 238 for examples.

12 Schaudig, Inschriften, 476.

13 See H. Tadmor, The Inscriptions of Tiglath-Pileser III King of Assyria (Jerusalem: The Israel Academy of Sciences and Humanities, 1994), Summary Inscription 7 23-24, p. 163.

14 For ease of reference, see J.N. Postgate, 'Trees and Timber in the Assyrian Texts', in Trees and Timber in Mesopotamia, Bulletin on Sumerian Agriculture 6 (1992) 177-92. 
reached at least as far west as Mari on the mid-Euphrates, where we find chairs, a footstool, a bed, a chariot and the handle of a razor made from its wood..$^{15}$

Of greater relevance to Isaiah 40:20 are two texts which connect musukkannu-wood more specifically with divine images. The first is an incantation associated with the Mesopotamian Mīs-pî ritual, which acknowledges the possibility that the divine image may have been constructed of musukkannu-wood. ${ }^{16}$ An inscription of Esarhaddon, on the other hand, speaks of a base, that is, the pedestal on which the divine image stood, constructed from musukkannu-wood for the goddess Tašmētum. Image and pedestal were located in the temple of Marduk in Babylon. In Isaiah 40:20 itself the reference is to one of these two possibilities, and both have their supporters. ${ }^{17}$

Given that the wood is frequently mentioned by the Assyrian kings, is it possible that the word was loaned into Hebrew at this time? It is possible, but it should be noted that if it did, it did not do so via the Assyrian language. This can be clearly seen from the sibilant that is used. In loan words from Assyrian into biblical Hebrew, Assyrian $\breve{s}$ is regularly represented as Hebrew $s$, and Assyrian $s$, by Hebrew $\check{s}$. Examples of this would be the Assyrian king's name Šarru-kén, Sargon in Hebrew, or the Assyrian word süqu, found in Hebrew as $\check{s} \hat{u} q$. In loan words from Babylonian, on the other hand, the sibilants correspond exactly.18 This, then, would be a loan from Babylonian.

What of the wood further west? Again it must be stated that to my knowledge there is no direct textual evidence for the presence of musukkannu-wood west of Mari. The Assyrian kings, for example, do not expressly receive any in tribute from western kings, nor is the

15 See J.-R. Kupper, 'Le Bois à Mari’, BSA 6, 166.

16 C.B.F. Walker and M. Dick, The Induction of the Cult Image in Ancient Mesopotamia: The Mesopotamian Mīs-pî Ritual (State Archives of Assyria Literary Texts 1; Helsinki: The Neo-Assyrian Text Corpus Project, 2001), 115, line 27. The line occurs within a fairly comprehensive list of possibilities. It appears that almost any kind of wood could have been used to make a divine image!

17 Williamson, 'Isaiah 40,20' favours two separate idols; A, Fitzgerald, 'The Technology of Isaiah 40:19-20 + 41:6-7', CBQ 51 (1989) 426-46 favours a base for the idol mentioned in verse 19. See also M.B. Dick, 'Prophetic Parodies of Making the Cult Image', in M.B. Dick (ed.), Born in Heaven, Made on Earth: The Making of the Cult Image in the Ancient Near East (Winona Lake: Eisenbrauns, 1999), 22 fn. h.

18 P.V. Mankowski, Akkadian Loanwords in Biblical Hebrew (HSS 47; Winona Lake: Eisenbrauns, 2000), 156. 
wood mentioned by name in the Amarna letters. However, it is probable that it was known there, at least lexically. Tablet III of the lexical series HAR-ra $=$ hubullu consists of a list of tree names. giš.mes.má.gan.na $=m u-s u-k a-n u$ appears in line 204 of this tablet. The list, or precursors of it, is attested at Emar, Alalakh, Ugarit, Ashkelon and Hazor. The Ashkelon fragment was found 'in a clear Late Bronze II context' and 'probably dates from about the thirteenth century B.C.E.'. ${ }^{19}$ It contains part of the first tablet. The fragment from Hazor is a 'school text', dating to the Old or Early Middle Babylonian period, and contains part of tablet II. If parts of this series have been discovered, then it is not unreasonable to suppose that more existed. If this argument is valid, then at least the name of the wood would have been known in Palestine in the second millennium BC.

The location of Palestine on the main trade route between Mesopotamia and Egypt again means that the wood may have become known in the west via trade in luxury items. It may be noted that ebony only occurs once in the Hebrew Bible, in Ezekiel 27:15. However, it was well known in Palestine. It was carried backwards and forwards in the Amarna age ${ }^{20}$ and was received as tribute from Hezekiah by Sennacherib. ${ }^{21}$ However, the major difference between ebony and musukkannu-wood is that the former is attested in Egyptian, Ugaritic and the Amarna letters, the latter in none of these. At the same time, we are at the mercy of the texts in this regard there are periods and places in Babylonia, for example, for which musukkannu is lacking textually, but lack of evidence is not in itself evidence for absence.

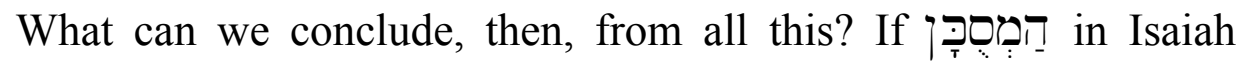
40:20 = Akkadian musukkannu, available evidence favours a Babylonian setting, or at least an awareness of Babylonian practice as the background for the composition of the polemic. At the same time, the possibility cannot be ruled out that the wood was also known in the west as a luxury item back into the second millennium BC. Consequently, this interpretation cannot be used without reserve to support a Babylonian location for 'II Isaiah'.

19 J. Huehnergard and W. van Soldt, 'A Cuneiform Lexical Text from Ashkelon with a Canaanite Column', IEJ 49 (1999) 184.

20 See, for example, W.L. Moran, The Amarna Letters (Baltimore and London: The Johns Hopkins University Press, 1992), EA 5, 14, 22, among others.

21 D.D. Luckenbill, The Annals of Sennacherib, Oriental Institute Publications II (Chicago: The University of Chicago Press, 1924), p. 34 III 45. 